
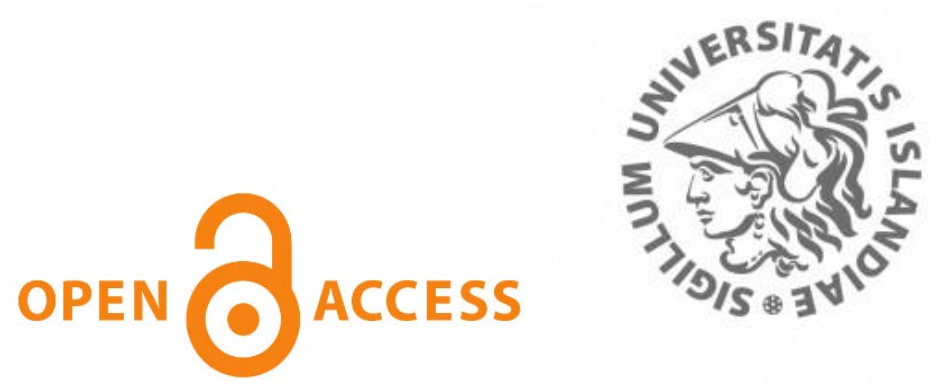

O. Opin vísindi

This is not the published version of the article / petta er ekki útgefna útgáfa greinarinnar

Author(s)/Höf.: $\quad$ Barrio IC, Hik DS, Thórsson J, Svavarsdóttir K, Marteinsdóttir B, Jónsdóttir IS

Title/Titill: $\quad$ The sheep in wolf's clothing? Recognizing threats for land degradation in Iceland using state-and-transition models

Year/Útgáfuár: $\quad 2018$

Version/Útgáfa: $\quad$ Pre-print / Óritrýnt handrit

Please cite the original version:

Vinsamlega vísið til útgefnu greinarinnar:

Barrio IC, Hik DS, Thórsson J,Svavarsdóttir K, Marteinsdóttir B, Jónsdóttir IS. The sheep inwolf's clothing? Recognizing threats for land degradation inlceland using state-and-transition models. Land Degrad Dev.2018;1-12. doi:10.1002/ldr.2978

Rights/Réttur: $\quad$ Copyright @ 1999-2018 John Wiley \& Sons, Inc. All rights reserved 


\title{
1 The sheep in wolf's clothing? Recognizing threats for land degradation in 2 Iceland using state-and-transition models
}

\author{
3 BARRIO, I.C. ${ }^{1,2,3 *}$, HIK, D.S. ${ }^{4}$,THÓRSSON, J. ${ }^{5}$, SVAVARSDÓTTIR, $\mathrm{K}^{5}{ }^{5}$, MARTEINSDÓTTIR, B. ${ }^{1,5}$, \\ 4 JÓNSDÓTTIR, I.S. ${ }^{1,6}$ \\ $5{ }^{1}$ Institute of Life and Environmental Sciences, University of Iceland, Sturlugata 7, 101 Reykjavík, Iceland \\ $6 \quad{ }^{2}$ Agricultural University of Iceland, Keldnaholt, 112 Reykjavík, Iceland \\ 7 3United Nations University Land Restoration Training Programme, Árleyni 22, 112 Reykjavík, Iceland \\ $8{ }^{4}$ Department of Biological Sciences, University of Alberta, Edmonton, Alberta, T6G 2E9, Canada \\ 95 Soil Conservation Service of Iceland, Gunnarsholt, 851 Hella, Iceland \\ 10 6University Centre in Svalbard, N-9171 Longyearbyen, Norway \\ 11 *corresponding author: icbarrio@gmail.com
}

12

13 ABSTRACT

14 Land degradation and extensive soil erosion are serious environmental concerns in Iceland. Natural 15 processes associated with a harsh climate and frequent volcanic activity have shaped Icelandic landscapes.

16 However, following human settlement and the introduction of livestock in the $9^{\text {th }}$ century the extent of soil

17 erosion rapidly escalated. Despite increased restoration and afforestation efforts and a considerable

18 reduction in sheep numbers during the late $20^{\text {th }}$ century, many Icelandic rangelands remain in poor

19 condition. A deeper understanding of the ecology of these dynamic landscapes is needed, and state-and-

20 transition models (STMs) can provide a useful conceptual framework. STMs have been developed for

21 ecosystems worldwide to guide research, monitoring and management, but have been used at relatively

22 small spatial scales and have not been extensively applied to high-latitude rangelands. Integrating the best

23 available knowledge, we develop STMs for rangelands in Iceland, where sheep grazing is often regarded as a

24 main driver of degradation. We use STMs at a country-wide scale for three time periods with different

25 historical human influence, from pre-settlement to present days. We also apply our general STM to a case

26 study in the central highlands of Iceland to illustrate the potential application of these models at scales

27 relevant to management. Our STMs identify the set of possible states, transitions and thresholds in these

28 ecosystems and their changes over time, and suggest increasing complexity in recent times. This approach

29 can help identify important knowledge gaps and inform management efforts and monitoring programmes,

30 by identifying realistic and achievable conservation and restoration goals.

31 Keywords: adaptive monitoring, land management, sheep grazing, rangeland 
32 Short title: State-and-transition models for rangelands in Iceland 


\section{INTRODUCTION}

34 Land degradation and environmental management pose constant challenges to natural resource managers,

35 farmers, researchers and policy makers. Understanding how ecosystems respond to disturbances and

36 management interventions is a fundamental step towards the development of effective management

37 strategies. In this context, state-and-transition models (STMs) can provide a useful conceptual framework to

38 guide monitoring, management and research. STMs synthesize and communicate knowledge about the

39 alternative states of an ecosystem, the causes of state transitions and the presence of thresholds, and offer

40 a framework for research into the processes driving the system (Bestelmeyer et al., 2003; Stringham et al.,

41 2003).

42 STMs emerged in the context of rangeland management (Westoby et al., 1989) to deal with discontinuities

43 and irreversible transitions in vegetation dynamics in grazing systems, and are typically applied at temporal

44 and spatial scales relevant to management (Bestelmeyer et al., 2003). Beyond rangelands, these models

45 have been widely adopted to synthesize information about state transitions in a variety of terrestrial

46 systems (Jefferies et al., 2006; Spooner \& Allcock, 2006). It is now widely recognized that in most systems,

47 changes in vegetation composition are often asymmetric and abrupt transitions can occur between

48 alternative vegetation states (Suding et al., 2004). For example, in rangelands the activities of herbivores

49 can interact with physical processes leading to discontinuous and non-reversible transitions. Herbivores can

50 initiate small changes to plant-soil systems that trigger positive feedbacks leading to rapid catastrophic shifts

51 in vegetative states and irreversible changes in soil properties (Jefferies et al., 2006; Van de Koppel et al.,

52 1997).

53 Most Icelandic ecosystems are used as extensive summer rangelands and sheep grazing is often considered

54 a main driver of land degradation. Extensive soil erosion in some parts of the country has been associated

55 with human settlement and the introduction of livestock grazing, coupled with harsh environmental

56 conditions and frequent volcanic activity (Arnalds, 1987). Intensive grazing and trampling by large mammals

57 can disrupt vegetation cover and expose bare ground to erosion by wind and water. In Iceland, the volcanic

58 origin of soils (Andosols) makes them highly susceptible to erosion, especially on younger soils within the

59 volcanic active zone and at higher elevation in the highlands (Arnalds, 2015). Once bare ground is exposed,

60 positive feedbacks are initiated that can lead to accelerated erosion processes (Aradóttir et al., 1992). The

61 concept of thresholds has been applied in Iceland to describe this catastrophic shift where ecosystems

62 collapse into a degraded state (Aradóttir et al., 1992; Archer \& Stokes, 2000), and the only attempt to apply

63 STMs to Icelandic ecosystems also focused on this transition (Thorsson, 2008). 
However, "less catastrophic" transitions are also likely; they may imply less obvious changes in the structure and function of the ecosystem, but may still have important management implications if the ability of the alternative states to provide valuable ecosystem services declines. Evidence for the occurrence of these thresholds is found in systems that fail to recover after removal of disturbance, for example when excluding grazing does not trigger changes leading to recovery. Once the system has shifted into an alternative state, releasing grazing pressure alone may not be sufficient to revert back to the previous state and intensive management actions, such as seeding or shrub control, may be required (Bestelmeyer et al., 2003). Such examples are relatively common in Iceland (Marteinsdóttir et al., 2017). For example, in some rangelands in the highlands no apparent plant community responses were detected after four years of grazing protection (Jónsdóttir et al., 2005). Even when longer time periods were considered in areas where grazing had been abandoned for $>60$ years, plant diversity did not differ from continuously grazed areas (Mörsdorf, 2015).

Our objective is to produce a state-and-transition modelling framework for rangelands in Iceland, to help understand landscape changes brought about by human settlement and human activities, relative to other drivers of change (climate fluctuations and environmental disturbances, such as volcanism), and to guide research, monitoring and management. We apply such framework at a large spatial and temporal scale, focusing on three periods with different human influence: before human settlement in the late $9^{\text {th }}$ century (pre-landnám), until 1900s (pre-industrial period) and after 1900s. Iceland provides a unique opportunity to try to disentangle the influence of different drivers of landscape change, because human influence can be

82 clearly tracked in the paleoenvironmental record and historical narratives. Here, we expand on the models

83 for birch woodland degradation in Iceland (Aradóttir et al., 1992; Archer \& Stokes, 2000; Thorsson, 2008) to

84 incorporate all possible vegetation states present and past, and describe the potential transitions and

85 thresholds between them. To illustrate the usefulness of such a framework we apply the post-1900s STM to a case study in the highlands of Iceland at a finer spatial scale that is more relevant to management.

\section{METHODS}

89 STMs are conceptual frameworks constructed around distinct ecosystem states and their possible changes 90 (transitions) under a given set of environmental drivers (e.g. disturbances). Narrative descriptions in STMs

91 are generally supported by different sources of data, from informal historical observations and expert 92 knowledge to controlled experiments (Bestelmeyer et al., 2009). To build the general STM framework for 93 Iceland we used a recent compilation on the ecological impacts of sheep grazing in Iceland (Marteinsdóttir 94 et al., 2017), paleoecological evidence, historical records and expert knowledge (for more details and 95 specific sources see Tables S1 and S2). 
The basic unit of STMs are the different ecosystem states (S), which are broadly characterized by their

97 vegetation structure and composition, the dominant ecosystem processes and their main ecosystem

98 attributes (Stringham et al., 2003); as such, states reflect land potential and are broadly defined by

99 topography, climate and soil characteristics. Generally, states are defined as units that are stable within

100 periods of time and spatial scales (e.g. 0.1-10 ha) relevant to land management (Bestelmeyer et al., 2003); in

101 our study however, we define states more broadly to encompass larger spatial and temporal scales (e.g.

102 Walker \& Westoby, 2011; Zhang et al., 2018). To build our general STM, we recognized different states for

103 rangelands in Iceland based on broad, structurally distinct habitat types (Ottósson et al., 2016; Figure 1).

104 States include different plant communities and dynamic soil properties (community phases).

105 Contrary to the shifts among community phases (pathways) within a state, transitions ( $T$ ) between states are

106 usually not reversible by simply altering the intensity or direction of the factors that produced the change.

107 Transitions may be gradual and cumulative, or non-linear and characterized by abrupt thresholds. Here, the

108 thresholds define the point beyond which ecological processes cannot maintain the sustained equilibrium of

109 the state any longer (Stringham et al., 2003). Based on the best available knowledge we identified all

110 possible transitions between the different ecosystem states and hypothesized the factors driving them, for

111 different time periods.

112 We separated our analyses into three different historical periods with contrasting human influence: 1)

113 before human settlement, 2) until 1900s (pre-industrial period) and 3) after 1900s. Shortly before

114 settlement, a volcanic ash layer was deposited almost everywhere in Iceland (Pórarinsson, 1961). This

115 Landnám tephra layer provides a precise litho-chrono-stratigraphic marker of human colonization in the

116 paleoenvironmental record, and facilitates the definition of the 'paleoanthropocene' in Iceland, as a period

117 of pre-industrial human influence (Streeter et al., 2015). Analyses of pre-settlement vegetation in Iceland

118 are based on pollen assemblages preserved in lake sediments and peat (Hallsdóttir, 1995), macrofossil

119 record and sediment analyses (Eddudóttir et al., 2016; Vickers et al., 2011). In addition to the

120 paleoenvironmental record, information on vegetation patterns after landnám is also available from

121 historical documents, like the Old Icelandic Sagas.

122 Case study: Auđkúluheiđi

123 We applied the post 1900s STM model to the rangelands in Auð̌kuluheiði to illustrate the ability of our 124 model to accommodate local case studies at spatial and temporal scales relevant to management.

125 Auðkúluheiði is a commons grazing area located in the northwest-central highlands of Iceland $\left(65^{\circ} 16^{\prime} \mathrm{N}\right.$,

$12620^{\circ} 15^{\prime} \mathrm{W}$ ) at $480 \mathrm{~m}$ elevation, about $150 \mathrm{~m}$ above the potential tree line. The area is outside the volcanic

127 active zone on basaltic bedrock with loose glacial deposits. Soils are well-drained Andosols with high cation 
exchange capacity and high water retention (Arnalds, 2015). Climate is oceanic-subarctic-alpine, with an

129 average annual temperature of $0.3^{\circ} \mathrm{C}$ and $397 \mathrm{~mm}$ of annual precipitation. Paleoecological information for

130 the area is available from Barđalækjartjörn, a lake on the north boundary of the communal grazing land

131 (Eddudóttir et al., 2016). The grazing lands in Auðkúluheiði are highly valued and a considerable amount of 132 research has been conducted in the area (Jónsdóttir, 1984; Magnússon \& Magnússon, 1992).

\section{RESULTS}

135 The general STMs increased in complexity with time, from the simplest pre-landnám model to the most 136 complicated present situation (Figures 2-4). We defined 8 possible ecosystem states and 11 potential 137 transitions (Table 1). Transitions were grouped when they represented the same process; for example, primary succession on barren lands (T7) could lead to moss/lichen dominated fields (T7a), birch woodlands

139 (T7b), wetlands (T7c), heathlands (T7d) or grasslands (T7e), depending on environmental conditions, 140 topography and substrate properties (Table 1 ).

142 Pollen of mountain birch (Betula pubescens Ehrh.) has been used as a proxy for the extent of birch

143 woodlands (S1; Figure 2, Table 1) in the paleoenvironmental record of Iceland. During the Holocene birch

144 woodlands were common in Iceland, but their extent fluctuated with variations in climate (Erlendsson \&

145 Edwards, 2009; Hallsdóttir, 1995). The cover of birch woodland at the time of settlement has been

146 estimated to be somewhere between 8\% (Ólafsdóttir et al., 2001) to 40\% of the country (Bjarnason, 1971),

147 with the most recent estimate of $24 \%$ (Wöll, 2008). Before human influence, colder periods drove

148 transitions from woodland to open landscapes $(\mathbf{T 1}, \mathbf{T 3}, \mathbf{T 5})$ dominated by wetland (S2) or heathland

149 vegetation (S3), depending on topography. Grasslands (S4) may have also occured on moister soils above

150 the treeline. Natural catastrophic events, like volcanic activity or glacial floods may have created barren

151 lands (S5) that would have acted as new primary successional habitats. Thus, without the influence of

152 humans and large herbivores, pre-settlement vegetation patterns were likely determined by topography and

153 substrate properties, and responded mainly to fluctuations in climate and aeolian processes (Eddudóttir et

154 al., 2016) and, on shorter time scales, to volcanism.

155 Although there is no clear evidence in the paleoenvironmental record, a likely primary successional stage are

156 fields dominated by mosses or lichens (S6). This state dominates many primary successional habitats today,

157 such as lava flows and glacier forelands (Cutler et al., 2008; Vilmundardóttir et al., 2015).

158 From landnám to 1900 s 
Paleo- and archeological records provide evidence for dramatic human impact on the environment shortly

160 after settlement (Dugmore et al., 2005; Eddudóttir et al., 2016; Streeter et al., 2015). For example, in the

161 lowlands, extensive clearing of birch woodlands in combination with livestock grazing, resulted in a rapid

162 transition to open grasslands (T5) and dwarf shrub heathlands (T4) that were less resilient to natural

163 catastrophes (Dugmore et al., 2005; Vickers et al., 2011). These changes are most evident around farms

164 (Erlendsson \& Edwards, 2010; Kristinsson, 1995) and in more densely populated areas (Pórarinsson, 1961).

165 The onset of human activity in Iceland was combined with a colder period, the Little Ice Age (1450 to 1920),

166 which implied more rapid declines in vegetation cover than before settlement (Haraldsson \& Ólafsdóttir,

167 2003). This colder period also implied that people's livelihoods became more dependent on livestock than

168 during the settlement period (Haraldsson \& Ólafsdóttir, 2006). The number of animals that could be

169 sustained depended partly on the availability of food during winter, either through access to winter grazing

170 areas or haymaking during summer (Arnalds \& Barkarson, 2003). Historical winter grazing contributed

171 significantly to accelerated land degradation close to some farms (Simpson et al., 2004), as livestock offtake

172 of vegetation would almost always exceed vegetation productivity in winter. Towards the end of this

173 period, ploughing and harrowing allowed the expansion of grassland and cultivated hay meadows (S4)

174 (Pórhallsdóttir et al., 2013).

175 The number of sheep began to increase in the 1820s when foreign markets opened up for sheep products

176 (Pórhallsdóttir et al., 2013). Simultaneously, traditional grazing practices changed; the shift in interest from

177 milk and dairy products to meat in the second half of the $19^{\text {th }}$ century meant that ewes no longer needed to

178 be grazed close to the farm so that they could be milked daily, and extensive summer grazing in the

179 highlands became more common (pórhallsdóttir et al., 2013). Consequently, the grazing pressure in

180 highland ranges increased considerably towards the end of the $19^{\text {th }}$ century. Overgrazing in some areas may

181 have led to the formation of landscapes dominated by soil erosion spots (Archer \& Stokes, 2000). These

182 degraded areas (S7) represent a transitory state (sensu Westoby et al., 1989) that is highly unstable and

183 leads to accelerated erosion and eventually the formation of barren areas.

184 Post-1900s

185 Human population in Iceland has steadily increased since the late 1890s (Haraldsson \& Ólafsdóttir, 2006).

186 Improved technology in haymaking and the introduction of artificial fertilizers allowed the numbers of sheep 187 to increase, reaching a maximum of 896,000 animals in 1977 (Arnalds \& Barkarson, 2003). A livestock quota

188 was introduced in 1985 but by the time the stocking rates were reduced, the ecosystems in many grazing

189 commons had already shifted to a severely degraded state (S5). The numbers of sheep are nowadays half of 190 those in the early 1980s but are still high relative to historical abundances (Marteinsdóttir et al., 2017). In 
191 parallel, improved access to winter fodder led to the gradual abandonment of winter grazing, reducing

192 grazing pressure around farms. Still, the recovery of vegetation in many areas after the release in grazing

193 pressure is slow (Bjarnason, 1971; Magnússon \& Svavarsdóttir, 2007).

194 From the perspective of land management and environmental protection the onset of the $20^{\text {th }}$ Century

195 implied great changes. Nation-wide efforts to halt soil erosion and subsequent sand encroachment began in

196 the early 1900s. A new law on soil conservation, revegetation and afforestation was passed in 1907, leading

197 to the foundation of two state institutions, the Soil Conservation Service and the Forestry Service

198 (Magnússon, 2000). Considerable revegetation of barren areas (T7) has been achieved, but afforestation,

199 and some revegetation efforts, also created a new man-made state, plantations (S8), dominated by

200 introduced species.

201 Organised measures to halt soil erosion and reclaim eroded land through controlled revegetation of eroded

202 areas started in the early 1900s (Magnússon, 2000; Olgeirsson, 2007). Commonly used methods involved

203 fertilizing and sowing of agronomic grasses (e.g. Festuca rubra, Phleum pratense, Deschampsia beringensis

204 and Lolium multiflorum) or native species, such as Lyme grass (Elymus arenarius) or to a lesser extent, $B$.

205 pubescens or Salix sp. shrubs. Other reclamation activities involved fencing off areas to exclude grazing

206 (Magnússon \& Svavarsdóttir, 2007), and from the early 1990s using fertilizers alone, or planting introduced

207 species like the Nootka lupine (Lupinus nootkatensis). The lupine was introduced to Iceland in the 1940s for

208 revegetation purposes (Magnusson, 2010), however it was not used on a large scale until after the Soil

209 Conservation Service of Iceland started to produce seed in the 1980s (Arnalds, 1988). Since then, the lupine

210 has spread greatly especially in disturbed habitats in the lowlands, but also encroaching into dwarf-shrub

211 heathlands (T11b in Figure 4), to the extent that it is now classified as an invasive species in Iceland

212 (Magnusson, 2010).

213 In the early days the main purpose of revegetation was to control soil erosion, rather than to direct plant

214 succession to specific pathways (Aradóttir et al., 2013). In the 1950s, due to the availability of new

215 technology, the emphasis shifted to the cultivation of grass on eroded land (T7e in Figure 4), using

216 commercial grass seeds and artificial fertilizers (Greipsson \& El-Mayas, 1999), with the aim of hay production

217 and rangeland improvement (Magnússon, 2000). After the mid 1980s an ecological approach to

218 revegetation was adopted, and greater emphasis was put on the development of sustainable ecosystems

219 (Aradóttir et al., 2013; Magnússon, 2000).

220 During the early 1900s forestry efforts focussed on preserving the remaining birch woodlands (Aradóttir \&

221 Eysteinsson, 2005), the cover of which during that period has been estimated to be $1 \%$ of the country

222 (Traustason \& Snorrason, 2008). Efforts to protect native birch woodland remnants date back to an act that 
was passed in 1899 to protect the woodlands; the first national forest, Hallormsstađaskógur was fenced off

224 in 1905-1908 (Bjarnason, 1971). Planting of exotic conifers started in the late 1930s. The government has

225 supported afforestation on farms since 1970, which has led to the transition of many grasslands (T11c) and

226 to a lesser extent heathlands, to forest plantations (T11b). Most forest plantations were carried out on

227 deforested areas, but in some places tree planting took place within natural birch woodlands (T11a)

228 (Traustason \& Snorrason, 2008).

229 Recent greening trends in some parts of Iceland (increases in NDVI) during 1982-2002 (Raynolds et al.,

230 2015), the expansion of non-native species, like planted conifers or the invasive Nootka lupine (Icelandic

231 Institute of Natural History, unpublished data), and increases in cover of birch woodland from 1.1 in 1989 to

$2321.5 \%$ in 2012 (Snorrason et al., 2016) are likely related to reductions in grazing, extensive revegetation and

233 afforestation efforts as well as climate warming and natural vegetation succession in areas of glacial retreat

234 (Raynolds et al., 2015; Vilmundardóttir et al., 2015).

Case study: Auđkúluheiði

237 Early Holocene records (10,300 to 8,000 cal. a BP) for Auðkúluheiði suggest the dominance of dwarf shrub

238 heathlands (S3) in the area, dominated by Betula nana, Salix sp. and Juniperus communis, together with

239 wetlands (S2) and sparsely vegetated rocky/sandy surfaces (S5) (Eddudóttir et al., 2016). Birch woodlands

240 may have expanded from lower elevations during a warmer period in the Holocene, but at the time of

241 settlement landscapes were already dominated by dwarf shrub heathlands (Eddudóttir et al., 2016). The

242 introduction of grazing livestock reduced the resilience of the ecosystem to volcanism and a cooling climate

243 during the Little Ice Age, as evidenced by increased soil erosion rates from the 9th Century (Eddudóttir et al., 244 2016).

245 The Auðkúluheiði commons have been extensively used as a summer rangeland for centuries (Jónsdóttir, 246 1984; Magnússon \& Magnússon, 1992). Indications of the natural vegetation of the heathlands without the 247 influence of grazing in this area are available from lake islands to which sheep have never had access 248 (Jónsdóttir, 1984; Kristinsson, 1979). Some species like Angelica archangelica were only found on the 249 islands, while others, like Geranium sylvaticum or tall native willow shrubs (Salix spp.) were less abundant in 250 the grazed areas (Kristinsson, 1979). Differences between grazed and non-grazed heathland vegetation 251 were more pronounced where growing conditions for plants were more favourable (Jónsdóttir, 1984).

252 Nowadays the landscape is dominated by extensively grazed heathlands (S3, Figure 5) and degraded (S7) 253 and barren areas (S5). Wetlands (S2) occur in depressions, and grasslands (S4) are restricted to managed 
areas close to old shieling areas or restoration sites (Thorsteinsson, 1991). Moss (S6) dominates ridgetops

255 that are not fully eroded (Jónsdóttir, 1984).

256 The post-1900s general STM (Figure 4) can be simplified to accommodate local case studies such as

257 Auðkúluheiði (Figure 5a). Because the model is applied to a smaller spatial and temporal scale, it can be

258 used to more directly infer how management would affect changes in the ecosystem over time (Figure 5b).

259 In the absence of grazing, the amount of exposed bare ground may vary with topography and exposure, but

260 is generally small (<10\% on average; Jónsdóttir, 1984). If sheep are present, the percentage of bare ground

261 is likely to increase over time, as trampling and selective foraging can disrupt vegetation cover, creating bare

262 ground patches that are open to erosion. It has been suggested that when exposed areas exceed $35 \%$ of the

263 surface (Thorsson, 2008), feedbacks will be initiated that lead to irreversible transitions of the landscapes to

264 degraded states (S7) and ultimately to barren lands (S5). This threshold value, however, needs to be taken

265 with caution, as it is based on a single estimate (Thorsson, 2008) and is likely to vary with topography and

266 exposure.

267 How quickly this stage is reached will depend on sheep densities; at high sheep densities the threshold will

268 be crossed earlier than at moderate sheep densities; under light grazing pressure this threshold may not be

269 crossed at all. Management interventions are likely to take place only when certain amount of exposed bare

270 ground is detected in the landscape ("bg1" in Figure 5b), which will occur earlier under high grazing pressure

271 ( $\left.t_{1}\right)$ than under moderate grazing pressure $\left(t_{3}\right)$. At this point, reducing sheep densities from high to

272 moderate grazing pressure (trajectory a) will delay crossing the functional threshold; strongly reducing

273 grazing pressure from high or moderate to low sheep densities (trajectories $b$ and $b_{1}$ ) will maintain the

274 amount of exposed soil, while completely excluding sheep (trajectories $\mathrm{c}$ and $\mathrm{c}_{1}$ ) could slowly reduce the

275 amount of bare ground. The original state without grazing (heathland) may not be completely reversed

276 within management time frames (e.g. Jónsdóttir et al., 2005), possibly because of the lack of propagules of

277 palatable species that have been kept at very low abundance as a result of centuries of grazing. Finally, once

278 the functional threshold is passed, reducing or excluding sheep grazing alone will not restore the vegetated

279 state (trajectory d), and more costly interventions, such as seeding and fertilization, would be needed to

280 restore vegetation cover (Thorsteinsson, 1991).

281

282 DISCUSSION

283 We developed state and transition models for rangelands in Iceland, at a large spatial scale, for historical 284 periods with increasing human influence. Typically, STMs are applied at smaller spatial scales that are 285 relevant to land managers, but we find the use of STMs at broader spatial and temporal scales provides a 
novel approach for better understanding of the forces driving the system and how they interact. The history

287 of human colonization in Iceland and a reasonably good documentation through the paleaoenvironmental

288 record and historical documents allowed constructing models for periods with different human influence at

289 a country-wide scale. Our models indicate increasing complexity over time, with human influence creating

290 new states and accelerating some transitions. Human impacts can widen the range of habitats in which

291 threshold dynamics can occur (Suding \& Hobbs, 2009). In Iceland, up to the 1900s, human influence

292 accelerated landscape degradation. Although mitigation efforts increased at the turn of the century,

293 extensive soil erosion had already become (and continues to be) the main environmental problem in Iceland

294 (Arnalds, 2005).

295 Long-term, sustained stresses, such as gradual changes in climate or grazing, can act as directional forcings

296 for incremental state transitions. Herbivores can drive transitions between ecosystem states in tundra

297 ecosystems (Van der Wal, 2006). For example, Zimov et al (1995) postulated that at the end of the

298 Pleistocene in Beringian ecosystems the large-scale transition from productive grass-dominated steppe to

299 unproductive moss-dominated tundra could be attributed to the extinction of Pleistocene mega-herbivores.

300 The influence of human management through extensive sheep grazing is evident in landscapes throughout

301 the North Atlantic region (Ross et al., 2016). The term "ovigenic landscape" (Buckland \& Dugmore, 1991)

302 has been used to describe the historical impact of sheep grazing on Icelandic ecosystems, where extensive

303 sheep grazing has been linked to land degradation (Arnalds, 1987). The impacts of grazing in Iceland might

304 be particularly severe, as volcanic soils are particularly prone to water and wind erosion; once bare ground is

305 exposed active soil erosion can become the dominant process in the landscape (Arnalds, 2015). In addition

306 to these long-term forcings, episodic perturbations can drive rapid transitions with unpredictable outcomes

307 (Archer \& Stokes, 2000). This might be the situation in Iceland, where grazing pressure is compounded by

308 climate and stochastic environmental disturbances, such as volcanic eruptions. Some species are more

309 sensitive to volcanic ash and aeolian deposition (Vilmundardóttir et al., 2009), processes that can suffocate

310 vegetation and accelerate subsequent erosion.

311 Generating a single model for an entire country and for a long time frame entails a considerable degree of

312 simplification. However, the simplicity of STMs is also one of their main strengths, as it facilitates the use of

313 these models as a communication tool (Grice \& MacLeod, 1994) and helps organizing our knowledge about a

314 system (Bestelmeyer et al., 2003). To guide decision-making and management more detailed models at

315 finer spatial and temporal scales are needed, as well as an acknowledgement of where and when some

316 transitions are likely to happen (i.e. land potential). The application of our STM to a grazing common in the

317 central highlands of Iceland illustrates how the general model can be adapted to particular situations and

318 the usefulness of this approach to guide management efforts. For example, our model suggests that 
management actions at different times will require different intensity of management interventions to achieve the desired restoration outcomes. Once thresholds have been passed, restoration may become

321 prohibitively expensive and with lesser probability of success. More intensive interventions may be needed

322 to lead to state changes, and research efforts could be directed to specific restoration actions. For example,

323 in Iceland the expansion of birch forests is limited by the isolation of patches and availability of seed sources,

324 so it has been suggested that actively establishing discrete patches of woodland scattered across the

325 landscape could facilitate natural recolonization by birch (Aradottir \& Halldorsson, 2017).

326 Our application of the general STM to a specific case study also illustrates the usefulness of these

327 approaches for environmental monitoring and the assessment of current land condition. By linking specific

328 indicators to STMs model developers can provide tools to help managers determine the state that land is in,

329 relative to its potential, and evaluate the probablity of a transition (Bestelmeyer et al., 2003, 2009). For

330 example, the amount of bare ground seems to be an important indicator for catastrophic transitions in

331 Iceland (Aradóttir et al., 1992; Thorsson, 2008). Other variables, like moss depth, through its influence on

332 vascular plants and soil properties (Gornall et al., 2007), might be indicative of state changes that do not

333 necessarily imply irreversible ecological thresholds. Different community attributes may respond differently

334 to grazing and climatic variability, so evaluation of a broad set of vegetation variables would provide a more

335 thorough interpretation of vegetation dynamics (Fernandez-Gimenez \& Allen-Diaz, 1999; Fuhlendorf et al.,

336 2001). However, as resources are often limited only a subset of variables can be monitored; selection of

337 these variables should be guided by specific research questions and the best available knowledge of the

338 system (Lindenmayer \& Likens, 2009).

339 In sum, STMs provide a solid framework that can be applied at broader spatial and temporal scales to

340 organize knowledge about a system and its main drivers of change. By including time periods before and

341 after human settlement in Iceland, our models allow identifying landscape changes brought about by human

342 activities including (but not restricted to) sheep grazing, relative to other drivers of change, such as climate

343 fluctuations and environmental disturbances. Increased complexity over time suggests that human activities

344 have a profound influence on landscape changes. These models also help put into perspective the perceived

345 damaging effect of sheep grazing on Icelandic ecosystems and how management can alleviate or worsen

346 these effects (i.e. the sheep in wolf's clothing). Identifying the potential drivers of ecosystem transitions and

347 where they are likely to be more influential is a critical step to inform management practices, especially

348 when drivers are related to land uses (e.g. grazing practices), because these drivers can be more easily

349 managed than others (e.g. climate-related changes). 


\section{ACKNOWLEDGEMENTS}

353 ICB was supported by a postdoctoral fellowship funded by the Icelandic Research Fund (Rannsóknasjóður, grant nr 152468-051) and AXA Research Fund (15-AXA-PDOC-307). DSH recieved support from the Natural

355 Sciences and Engineering Research Council (Canada), and ISJ from the University of Iceland Research Fund.

356 The authors declare no conflict of interest.

\section{REFERENCES}

Aradóttir ÁL, Arnalds Ó, Archer S. 1992. Hnignun gróđurs og jarđvegs. In: Arnalds A (ed) Græđum Ísland. Landgræđsla Ríkisins: Reykjavik, 73-82

Aradóttir ÁL, Eysteinsson T. 2005. Restoration of birch woodlands in Iceland. In: Stanturf JA and Madsen P (eds) Restoration of boreal and temperate forests. CRC press, 195-209

Aradottir AL, Halldorsson G. 2017. Colonization of woodland species during restoration: seed or safe site limitation? Restoration Ecology 1-11. DOI: 10.1111/rec.12645

Aradóttir ÁL, Petursdottir T, Halldorsson G, Svavarsdottir K, Arnalds O. 2013. Drivers of Ecological Restoration: Lessons from a Century of Restoration in Iceland. Ecology and Society 18: 33. DOI: 10.5751/ES-05946-180433

Archer S, Stokes C. 2000. Stress, disturbance and change in rangeland ecosystems. In: Arnalds Ó and Archer S (eds) Rangeland desertification. Kluwer Academic Publishers, 17-38

Arnalds A. 1987. Ecosystem disturbance in Iceland. Arctic and Alpine Research 19: 508-513. DOI: 10.2307/1551417

Arnalds A. 1988. Lúpínan og landgræðslan. In: Arnalds A (ed) Græðum Ísland - Landgræðslan 1907-1987. Landgræðsla ríkisins: Gunnarsholt, 193-196

Arnalds A. 2005. Approaches to landcare -- a century of soil conservation in Iceland. Land Degradation \& Development 125: 113-125. DOI: $10.1002 / \mathrm{ldr} .665$

Arnalds Ó. 2015. The soils of Iceland. Springer: Dordrecht, the Netherlands

Arnalds O, Barkarson BH. 2003. Soil erosion and land use policy in Iceland in relation to sheep grazing and government subsidies. Environmental Science and Policy 6: 105-113. DOI: 10.1016/S1462-9011(02)00115-6

Bestelmeyer BT, Brown JR, Havstad KM, Alexander R, Herrick JE, Journal S, Mar N, Management R, Manage JR, Bestelmeyer BT, Brown JR, Havstad KM, Alexander R, Herrick JE. 2003. Development and use of state-andtransition models for rangelands. Journal of Range Management 56: 114-126

Bestelmeyer BT, Tugel AJ, Peacock GL, Robinett DG, Shaver PL, Brown JR, Herrick JE, Sanchez H, Havstad KM. 2009. State-and-transition models for heterogeneous landscapes: a strategy for development and application. Rangeland Ecology \& Management 62: 1-15. DOI: 10.2111/08-146

Bjarnason H. 1971. Um friðun lands og frjósemi jarðvegs. Ársrit Skógræktarfélags Íslands 4-19

Buckland PC, Dugmore A. 1991. If this is a refugium, why are my feet so bloody cold? The origins of the Icelandic biota in the light of recent research. In: Maizels JK and Caseldine C (eds) Environmental Change in Iceland: Past and Present. Kluwer Academic Publishers, 107-125. DOI: 10.1007/978-94-011-3150-6

Cutler NA, Belyea LR, Dugmore AJ. 2008. Spatial patterns of microsite colonisation on two young lava flows on Mount Hekla, Iceland. Journal of Vegetation Science 19: 277-286. DOI: 10.3170/2008-8-18371

Dugmore AJ, Church MJ, Buckland PC, Edwards KJ, Lawson I, McGovern TH, Panagiotakopulu E, Simpson IA, Skidmore P, Sveinbjarnardóttir G. 2005. The Norse landnám on the North Atlantic islands: an environmental impact assessment. Polar Record 41: 21-37. DOI: 10.1017/S0032247404003985

Eddudóttir SD, Erlendsson E, Tinganelli L, Gísladóttir G. 2016. Climate change and human impact in a sensitive ecosystem: The Holocene environment of the Northwest Icelandic highland margin. Boreas 45: 715-728. DOI: 10.1111 /bor.12184

Erlendsson E, Edwards KJ. 2009. The timing and causes of the final pre-settlement expansion of Betula pubescens in Iceland. The Holocene 19: 1083-1091. DOI: 10.1177/0959683609341001

Erlendsson E, Edwards KJ. 2010. Gróđurfarsbreytingar á Íslandi við landnám. Árbók Hins Íslenska Fornleifafélags 29-55 
Fernandez-Gimenez ME, Allen-Diaz B. 1999. Testing a non-equilibrium model of rangeland vegetation dynamics in Mongolia. Journal of Applied Ecology 36: 871-885. DOI: 10.1046/j.1365-2664.1999.00447.x

Fuhlendorf SD, Briske DD, Smeins FE. 2001. Herbaceous vegetation change in variable rangeland environments: the relative contribution of grazing and climatic variability. Applied Vegetation Science 4: 177-188. DOI: 10.1111/j.1654-109X.2001.tb00486.x

Gornall JL, Jónsdóttir IS, Woodin SJ, Van der Wal R. 2007. Arctic mosses govern below-ground environment and ecosystem processes. Oecologia 153: 931-41. DOI: 10.1007/s00442-007-0785-0

Greipsson S, El-Mayas H. 1999. Large-scale reclamation of barren lands in Iceland by aerial seeding. Land Degradation \& Development 10: 185-193. DOI: 10.1002/(SICI)1099-145X(199905/06)10:3<185::AID-LDR327>3.0.CO;2-R

Grice AC, MacLeod N. 1994. State and transition models for rangelands. 6. State and transition models as aids to communication between scientists and land managers. Tropical Grasslands 28: 241-246

Hallsdóttir M. 1995. On the pre-settlement history of Icelandic vegetation. Búvisindi 9: 17-29

Haraldsson H V., Ólafsdóttir R. 2003. Simulating vegetation cover dynamics with regards to long-term climatic variations in sub-arctic landscapes. Global and Planetary Change 38: 313-325. DOI: 10.1016/S0921-8181(03)00114-0

Haraldsson H V., Ólafsdóttir R. 2006. A novel modelling approach for evaluating the preindustrial natural carrying capacity of human population in Iceland. Science of the Total Environment 372: 109-119. DOI: 10.1016/j.scitotenv.2006.08.013

Jefferies RL, Jano AP, Abraham KF. 2006. A biotic agent promotes large-scale catastrophic change in the coastal marshes of Hudson Bay. Journal of Ecology 94: 234-242. DOI: 10.1111/j.1365-2745.2005.01086.x

Jónsdóttir IS. 1984. Áhrif beitar á gróđur Auđkúluheiđar. Náttúrufræđingurinn 53: 19-40

Jónsdóttir IS, Magnússon B, Gudmundsson J, Elmarsdóttir Á, Hjartarson H. 2005. Variable sensitivity of plant communities in Iceland to experimental warming. Global Change Biology 11: 553-563. DOI: 10.1111/j.13652486.2005.00928.x

Kristinsson H. 1979. Gróđur í beitarfriðuðum hólmum á Auðkúluheiði og í Svartárbugum. Týli 9: 33-46

Kristinsson H. 1995. Post-settlement history of Icelandic forests. Búvísindi Icelandic Agricultural Sciences 9: 31-35

Lindenmayer DB, Likens GE. 2009. Adaptive monitoring: a new paradigm for long-term research and monitoring. Trends in Ecology \& Evolution 24: 482-6. DOI: 10.1016/j.tree.2009.03.005

Magnusson B. 2010. NOBANIS - Invasive Alien Species Fact Sheet - Lupinus nootkatensis. Online Database of the European Network on Invasive Alien Species, 1-7

Magnússon B, Magnússon SH. 1992. Rannsóknir á gróđri og plöntuvali sauđfjár í beitartilraun á Auđkúluheiđi. Fjölrit RALA 159: 1-79

Magnússon SH. 2000. Restoration of eroded areas in Iceland. In: Urbanska KM, Webb NR and Edwards PJ (eds) Restoration ecology and sustainable development, 188-211

Magnússon SH, Svavarsdóttir K. 2007. Áhrif beitarfriðunar á framvindu gróđurs og jarđvegs á lítt grónu landi. Fjölrit Náttúrufræđistofnunar 49: 1-67

Marteinsdóttir B, Barrio IC, Jónsdóttir IS. 2017. Assessing the ecological impacts of extensive sheep grazing in Iceland. Icelandic Agricultural Sciences 30: 55-72. DOI: 10.16886/IAS.2017.07

Mörsdorf MA. 2015. Effects of local and regional drivers on plant diversity within tundra landscapes. University of Iceland

Ólafsdóttir R, Schlyter P, Haraldsson H V. 2001. Simulating Icelandic vegetation cover during the Holocene. Implications for long-term land degradation. Geografiska Annaler 83: 203-215. DOI: 10.1111/j.0435-3676.2001.00155.x

Olgeirsson FG. 2007. Sáđmenn sandanna - saga landgræđslu á Íslandi 1907-2007. Landgræđsla ríkisins.: Reykjavík

Ottósson JG, Sveisdóttir A, Harđadóttir M. 2016. Vistgerđir á Íslandi. Fjölrit Nátturufræđistofnunar 54: 1-299

Raynolds M, Magnússon B, Metúsalemsson S, Magnússon SH. 2015. Warming, sheep and volcanoes: land cover changes in Iceland evident in satellite NDVI trends. Remote Sensing 7: 9492-9506. DOI: 10.3390/rs70809492

Ross LC, Austrheim G, Asheim L-J, Bjarnason G, Feilberg J, Fosaa AM, Hester AJ, Holand $\varnothing$, Jonsdottir IS, Mortensen LE, Mysterud A, Olsen E, Skonhoft A, Speed JDM, Steinheim G, Thompson DBA, Thorshallsdottir AG. 2016. Sheep grazing in the North Atlantic region: A long-term perspective on environmental sustainability. Ambio 45: 551-566. DOI: 10.1007/s13280-016-0771-z

Simpson IA, Guðmundsson G, Thomson AM, Cluett J. 2004. Assessing the role of winter grazing in historic land degradation, Mývatnssveit, northeast Iceland. Geoarchaeology 19: 471-502. DOI: 10.1002/gea.20006

Snorrason A, Traustason B, Kjartansson BP, Heiđarsson L, Ísleifsson R, Eggertsson Ó. 2016. Náttúrulegt birki á Íslandi. Náttúrufræđingurinn 86: 97-111

Spooner PG, Allcock KG. 2006. Using a state-and-transition approach to manage endangered Eucalyptus albens (White Box) woodlands. Environmental Management 38: 771-783. DOI: 10.1007/s00267-005-0133-2

Streeter R, Dugmore AJ, Lawson IT, Erlendsson E, Edwards KJ. 2015. The onset of the palaeoanthropocene in Iceland: 
Changes in complex natural systems. The Holocene 25: 1662-1675. DOI: 10.1177/0959683615594468

Stringham TKK, Krueger WCC, Shaver PLL. 2003. State and transition modeling: an ecological process approach. Journal of Range Management 56: 106-113. DOI: 10.2307/4003893

Suding KN, Gross KL, Houseman GR. 2004. Alternative states and positive feedbacks in restoration ecology. Trends in Ecology and Evolution 19: 46-53. DOI: 10.1016/j.tree.2003.10.005

Suding KN, Hobbs RJ. 2009. Threshold models in restoration and conservation: a developing framework. Trends in Ecology and Evolution 24: 271-279. DOI: 10.1016/j.tree.2008.11.012

Thorsson J. 2008. Desertification of high latitude ecosystems: conceptual models, time-series analyses and experiments. Texas A\&M University

Thorsteinsson I. 1991. Uppgræđsla á Auðkúluheiði og Eyvindarstađaheiði 1981-1989. Fjölrit RALA 151: 1-133

Traustason B, Snorrason A. 2008. Spatial distribution of forests and woodlands in Iceland in accordance with the CORINE land cover classification. Icelandic Agricultural Sciences 21: 39-47

Van de Koppel J, Rietkerk M, Weissing FJ. 1997. Catastrophic vegetation shifts and soil degradation in terrestrial grazing systems. Trends in Ecology and Evolution 12: 352-356. DOI: 10.1016/S0169-5347(97)01133-6

Van der Wal R. 2006. Do herbivores cause habitat degradation or vegetation state transition? Evidence from the tundra. Oikos 114: 177-186. DOI: 10.1111/j.2006.0030-1299.14264.x

Vickers K, Erlendsson E, Church MJ, Edwards KJ, Bending J. 2011. 1000 years of environmental change and human impact at Stora-Mork, southern Iceland: A multiproxy study of a dynamic and vulnerable landscape. The Holocene 21: 979-995. DOI: 10.1177/0959683611400201

Vilmundardóttir OK, Gísladóttir G, Lal R. 2015. Between ice and ocean; soil development along an age chronosequence formed by the retreating Breiðamerkurjökull glacier, SE-Iceland. Geoderma 259-260: 310-320. DOI: 10.1016/j.geoderma.2015.06.016

Vilmundardóttir OK, Magnússon B, Gisladóttir G, Magnússon SH. 2009. Áhrif sandfoks á mólendisgróđur við Blöndulón. Náttúrufræđingurinn 78: 125-138

Walker B, Westoby M. 2011. States and transitions: The trajectory of an idea, 1970-2010. Israel Journal of Ecology \& Evolution 57: 17-22. DOI: 10.1560/IJEE.57.1-2.17

Westoby M, Walker B, Noy-Meir I. 1989. Opportunistic management for rangelands not at equilibrium. Journal of Range Management 42: 266-274. DOI: 10.2307/3899492

Wöll C. 2008. Treeline of mountain birch (Betula pubescens Ehrh.) in Iceland and its relationship to temperature. Technical University Dresden

Zhang G, Biradar CM, Xiao X, Dong J, Zhou Y, Qin Y, Zhang Y, Liu F, Ding M, Thomas RJ. 2018. Exacerbated grassland degradation and desertification in Central Asia during 2000-2014. Ecological Applications 28: 442-456. DOI: 10.1002/eap.1660

Zimov SA, Chuprynin VI, Oreshko AP, Chapin III FS, Reynolds JF, Chapin M. 1995. Steppe-tundra transition: a herbivoredriven biome shift at the end of the Pleistocene. The American Naturalist 146: 765-794. DOI: 10.1086/285824

Pórarinsson S. 1961. Uppblástur á Íslandi í ljósi öskulagarannsókna. Ársrit Skógræktarfélags íslands 17-51

Pórhallsdóttir AG, Júlíusson AD, Ögmundardóttir H. 2013. The sheep, the market and the soil: Environmental destruction in the Icelandic highlands 1880-1910. In: Jørgensen D and Sorlin S (eds) Northscapes: History, technology and the making of northern environments. University of British Columbia Press: Vancouver, BC, 153-173 
Table 1. Description of ecosystem states (S) in Iceland and possible transitions (T) between states and their potential drivers, as shown in Figures 2-4. Note that drivers are different and act over different time-scales for each of the models. For more details on each state and transition and relevant references see Tables S1 and S2. Correspondence with the habitat types described by Ottóson et al (2016) are indicated for each state.

\begin{tabular}{|c|c|c|c|}
\hline State & & Description & Habitat type \\
\hline S1 & Birch woodland & $\begin{array}{l}\text { Mountain birch (Betula pubescens) forests generally have a lush } \\
\text { herbaceous ground cover. Potential treeline is determined by altitude } \\
\text { (summer temperature) and proximity to the coast (i.e. less continental } \\
\text { climate). }\end{array}$ & L11 Woodlands \\
\hline S2 & $\begin{array}{l}\text { Wetland } \\
\text { communities }\end{array}$ & $\begin{array}{l}\text { Wetlands are dominated by sedges, rushes and graminoids. Wetlands } \\
\text { occur in depressions where ground water reaches the surface, or on } \\
\text { areas with less permeable bedrock. Depending on hydrology and the } \\
\text { presence of species adapted to drier conditions, saturated and damp } \\
\text { wetlands can be distinguished. }\end{array}$ & L8 Wetlands \\
\hline S3 & Heathlands & $\begin{array}{l}\text { Heathlands are dominated by shrubs, perennial graminoids and } \\
\text { occasionally mosses. Heathlands are determined climatically (i.e. } \\
\text { above treeline) or by human practices (e.g. clear-cutting). Grazing can } \\
\text { change the composition of heathlands, from heathlands dominated by } \\
\text { palatable species like Salix sp. shrubs, to heathlands dominated by less } \\
\text { palatable species like dwarf birch (Betula nana). }\end{array}$ & L10 Heathlands \\
\hline S4 & $\begin{array}{l}\text { Grassland } \\
\text { communities }\end{array}$ & $\begin{array}{l}\text { Grasslands are dominated by grasses and other graminoids. They are } \\
\text { to a large extent related to human uses (sheep grazing) in Iceland, but } \\
\text { they may occur naturally above treeline on moister soils than } \\
\text { heathlands. }\end{array}$ & L9 Grasslands \\
\hline S5 & Barren areas & $\begin{array}{l}\text { Areas with very sparse vegetation cover }(<5 \%) \text { where only the mineral } \\
\text { surfaces, glacial till or frost-heaved gravel remain. This state includes } \\
\text { also deserts and other primary succession habitats. }\end{array}$ & $\begin{array}{l}\text { L1 Fell fields, } \\
\text { morraines and } \\
\text { sands; L2 Exposed } \\
\text { aeolian soils }\end{array}$ \\
\hline S6 & $\begin{array}{l}\text { Moss/lichen } \\
\text { dominated fields }\end{array}$ & $\begin{array}{l}\text { The occurrence of thick moss carpets may be topographically } \\
\text { determined (e.g. on some ridgetops), or on primary successional } \\
\text { habitats such as lava flows. }\end{array}$ & $\begin{array}{l}\text { L5 Moss lands; L6 } \\
\text { Lava fields }\end{array}$ \\
\hline S7 & Degraded areas & $\begin{array}{l}\text { This state is the result of increased abundance and size of soil erosion } \\
\text { spots in woodlands (S1), heathlands (S3) or grasslands (S4), generaly } \\
\text { as a result of inadequate management. This is a transient state (sensu } \\
\text { Westoby et al., 1989) that will change rapidly into barren areas once } \\
\text { active erosion processes are in place. }\end{array}$ & $\begin{array}{l}\text { L2 Exposed } \\
\text { aeolian soils }\end{array}$ \\
\hline S8 & Plantations & $\begin{array}{l}\text { Man-made patches involving non-native species that become } \\
\text { persistent in the landscape, either for reclamation or forestry. }\end{array}$ & $\begin{array}{l}\text { L14 Other land } \\
\text { types }\end{array}$ \\
\hline \multicolumn{2}{|c|}{ Transitions } & \multicolumn{2}{|l|}{ Potential drivers } \\
\hline \multirow[t]{2}{*}{ T1 } & $\mathrm{S} 1 \rightarrow \mathrm{S} 2$ & \multicolumn{2}{|c|}{$\begin{array}{l}\text { Changes in hydrological regimes caused for example by retreat of glaciers due to climate } \\
\text { changes, and human intervention (e.g. in some areas clearcutting can cause the water table } \\
\text { to rise because ground water levels are no longer suppressed by woody vegetation after } \\
\text { trees are removed). This transition is unlikely on decadal time-scales. }\end{array}$} \\
\hline & $\mathrm{S} 2 \rightarrow \mathrm{S} 1$ & \multicolumn{2}{|c|}{$\begin{array}{l}\text { The transition from wetlands to woodlands would require changes in hydrological regimes. } \\
\text { This transition is unlikely on decadal time-scales. }\end{array}$} \\
\hline \multirow[t]{2}{*}{ T2 } & S2 $\rightarrow$ S3 & \multicolumn{2}{|c|}{ Prolonged droughts or human intervention (drainage). } \\
\hline & S3 $\rightarrow$ S2 & \multicolumn{2}{|c|}{$\begin{array}{l}\text { Prolonged periods of high rainfall and alteration of surface or subsurface water flow and } \\
\text { soil moisture. These changes could be driven by hydrological changes associated to glacial } \\
\text { recession can raise the water table and form bogs, or by human efforts to restore wetlands, } \\
\text { but in general this transition is unlikely on decadal time-scales.. }\end{array}$} \\
\hline
\end{tabular}




\begin{tabular}{|c|c|c|}
\hline \multirow[t]{2}{*}{ T3 } & $\mathrm{S} 2 \rightarrow \mathrm{S} 4$ & Natural changes in hydrological regimes, or human intervention (drainage). \\
\hline & S4 $\rightarrow$ S2 & Same as T2 (transition from heathlands to wetlands). \\
\hline \multirow[t]{2}{*}{ T4 } & S1 $\rightarrow$ S3 & $\begin{array}{l}\text { Changes in climate that cause treeline recession, and human intervention either through } \\
\text { deforestation and/or grazing on well-drained soils. }\end{array}$ \\
\hline & S3 $\rightarrow$ S1 & $\begin{array}{l}\text { Changes in climate towards warmer conditions can lead to the expansion of birch } \\
\text { woodlands. Restoration of birch woodlands on heathland can be achieved through fencing } \\
\text { off sheep and horses; regeneration of birch woodlands can be accelerated by planting and } \\
\text { sowing. }\end{array}$ \\
\hline \multirow[t]{2}{*}{ T5 } & S1 $\rightarrow$ S4 & $\begin{array}{l}\text { Changes in climate that cause treeline recession, for example during colder periods, and } \\
\text { human intervention either through deforestation and/or grazing on moister soils. }\end{array}$ \\
\hline & S4 $\rightarrow$ S1 & $\begin{array}{l}\text { Changes in climate towards warmer conditions can lead to the expansion of birch } \\
\text { woodlands given that seed sources are available. Protection from grazing can also favour } \\
\text { this transition. }\end{array}$ \\
\hline \multirow[t]{2}{*}{ T6 } & S3 $\rightarrow$ S4 & $\begin{array}{l}\text { Changes in soil conditions (increase in soil moisture due to for example altered } \\
\text { precipitation regimes), grazing or active human management (shrub clearing, fertilization) } \\
\text { could reduce the amount of shrubs. In heathlands where mosses are dominant, livestock } \\
\text { trampling could favour changes towards graminoid-dominated states. }\end{array}$ \\
\hline & S4 $\rightarrow$ S3 & Grazing abandonment and changes in climate (warming) could lead to shrub expansion. \\
\hline \multirow[t]{2}{*}{ T7 } & $\begin{array}{l}\text { S1, S2, S3, S4, S6 } \rightarrow \\
\text { S5 }\end{array}$ & $\begin{array}{l}\text { Catastrophic events (e.g. volcanic eruptions, glacial river floods) and enhanced aeolian } \\
\text { processes (e.g. sand encroachment) that cause vegetation die-off, opening of bare ground } \\
\text { patches and subsequent soil erosion. Adverse climatic conditions, like colder periods, can } \\
\text { intensify the effect of grazing and other disturbances (e.g. frequent tephra deposition, sand } \\
\text { encroachment, glacial river floods) promoting the formation of barren areas. }\end{array}$ \\
\hline & $\begin{array}{l}\text { S5 } \rightarrow \text { S1, S2, S3, S4, } \\
\text { S6 }\end{array}$ & $\begin{array}{l}\text { Primary succession occurs under favourable climatic conditions for the establishment of } \\
\text { vegetation (e.g. increased snow cover in winter that reduces the frequency of freeze-thaw } \\
\text { cycles, and warm summers with sufficient precipitation). In many cases, primary succession } \\
\text { will occur over time-scales longer than decades. Protection from grazing and climate } \\
\text { warming, as well as restoration and revegetation efforts can accelerate this transition. }\end{array}$ \\
\hline T8 & S6 $\rightarrow$ S1, S3, S4 & $\begin{array}{l}\text { Opening gaps in the moss layer, or reducing its thickness through trampling can allow the } \\
\text { establishment of other species, such as graminoids, leading to changes in plant community } \\
\text { composition. }\end{array}$ \\
\hline \multirow[t]{2}{*}{ T9 } & S1, S3, S4, S6 $\rightarrow$ S7 & $\begin{array}{l}\text { Trampling and plant consumption by livestock disrupts the plant biomass thermal barrier } \\
\text { that amplifies freeze-thaw dynamics destabilizing the highly erodible andosol soils and } \\
\text { making them more prone to frequent, small scale disturbances associated with frost boils, } \\
\text { frost heaving and needle-ice formation. }\end{array}$ \\
\hline & S7 $\rightarrow$ S1, S3, S4, S6 & $\begin{array}{l}\text { Considerably reduced or no grazing and climatic conditions favourable for the } \\
\text { establishment of vegetation (e.g. increased snow cover in winter that reduces the } \\
\text { frequency of freeze-thaw cycles, and warm summers with sufficient precipitation). This } \\
\text { transition involves a functional threshold, so it is not easily reversed, especially over } \\
\text { decadal time-scales. }\end{array}$ \\
\hline T10 & S7 $\rightarrow$ S5 & $\begin{array}{l}\text { This transition is unidirectional in a decadal time-scale. A positive feedback is initiated } \\
\text { where rates of expansion of eroded patches increase with increasing patch size. Surfaces } \\
\text { and escarpments create active erosion fronts whose vertical faces (rofabards) are fully } \\
\text { exposed to further wind and water erosion. }\end{array}$ \\
\hline \multirow[t]{2}{*}{ T11 } & S1, S2, S4, S5 $\rightarrow$ S8 & Afforestation or reclamation efforts and natural expansion of plantations. \\
\hline & S8 $\rightarrow$ S1, S2, S4, S5 & $\begin{array}{l}\text { Natural dieback because of climatic mismatch of planted trees, disease (e.g. larch dieback } \\
\text { or the pine wooly aphid), or natural recession of some patches of Nootka lupine and human } \\
\text { efforts to eradicate invasive species. }\end{array}$ \\
\hline
\end{tabular}


503 Figure 1. Representative photos of the eight different terrestrial ecosystem states identified in this study for 504 rangelands in Iceland.

505 Figure 2. State-and-transition models for the time before settlement (pre-landnám) in Iceland. Possible 506 ecosystem states $(\mathrm{S})$ are indicated by boxes and transitions $(\mathrm{T})$ are shown as the arrows connecting the 507 boxes; arrow thickness suggests the probablility of each transition. Drivers of transitions in this model act 508 over long time-scales. Within each state, several community phases (shaded boxes) and community 509 pathways (dotted arrows) might be possible. The functional threshold (dashed line) indicates an irreversible 510 transition. See Tables 1, S1 and S2 for detailed descriptions of states and transitions.

511 Figure 3. State-and-transition models for the time between landnám and 1900s. Human settlement in 512 Iceland (landnám) brought livestock grazing, clearcutting and agricultural use mostly of lowland areas for 513 haymaking and cereal production. See Figure 2 for details; transitions mediated by grazing are indicated with 514 sheep symbols. Thickness of the arrows suggests the likelihood of the transitions; note changes from 515 previous period. Drivers of transitions in this model act over intermediate time-scales (i.e. centuries).

516 Figure 4. State-and-transition models for the time post-1900s. Soil erosion and land degradation became a 517 main environmental concern in Iceland in the early 1900s, when restoration and reforestation efforts began 518 (e.g. establishment of the Soil Conservation Service of Iceland in 1907). Drivers of transitions in this model 519 act over decadal time-scales (see Table 1 and S2). Arrows acknowledge the possibility of a transition 520 between two states; some transitions may occur with a very low probability (e.g. only under certain 521 conditions of topography, climate or soil type), or are highly unlikely at this time-scale (indicated by thin 522 arrows). See Figure 2 for details; transitions mediated by grazing are indicated with sheep symbols.

523 Figure 5. Simplified state-and-transition model for summer rangelands in Auðkúluheiði, in the central 524 highlands of Iceland based on the post-1900s model (a), and proposed changes over time in the relative cover of bare ground cover (as a proxy for land degradation) in response to different management interventions (b). Over time, sheep grazing increases the area of exposed bare ground (solid lines; intensity of grazing pressure is indicated by the number of sheep symbols). When exposed areas exceed $35 \%$ (dashed orange line; functional threshold and upper limit for $\mathrm{S} 3$, the heathland state) feedback processes will lead to irreversible transitions towards degraded states (S7) and, ultimately, barren lands (S5). Different ecosystem trajectories (discontinuous blue lines) will follow management interventions (red dots), such as reducing to moderate (trajectories a) or low (trajectory b) grazing pressure, or totally excluding grazing (trajectory c), implemented at different points in time $\left(t_{1}, t_{2}, t_{3}\right)$. Once the functional threshold is crossed, reducing or excluding sheep grazing alone will not restore the vegetated state, and more costly interventions, such as seeding and fertilizing, would be needed to restore vegetation cover (trajectory d). 